\title{
Fruit Wastes Hydrolysates as Feedstock: Pre-Treatment Strategies for Cost-Saving and Sustainable Microalgae Cultivation
}

\author{
Bikash Limbu and Sibi G* \\ Department of Biotechnology, Indian Academy Degree College-Autonomous, Bengaluru, India \\ *Corresponding Author: gsibii@gmail.com
}

\begin{abstract}
The aim of this study is to maximize the biomass and lipid accumulation in microalgae by using various hydrolysates of fruit wastes as growth medium. Chlorella vulgaris was cultivated in fruit hydrolysates medium pre-treated by enzymatic, aqueous and acid hydrolysis. The potential of carbohydrate and nutrient rich fruit waste for biomass and biofuel production by microalgae was investigated based on the hydrolysis approach. Hydrolyzed fruit wastes from three different pre-treatment methods were compared for microalgae cultivation for growth and lipid production. The results clearly showed that fruit waste hydrolysates pretreated with enzymes was more suitable than acid and aqueous hydrolysates and could be able to increase growth and lipid accumulation in microalgae.
\end{abstract}

Keywords: Microalgae, fruit wastes, hydrolysates, Chlorella, lipid, biomass

\section{INTRODUCTION}

Today's world is highly dependent on fossil resources as a supply of energy and depletion of finite fossil fuels would result in a global concern. It is estimated that major portion of world population depends on the energy derived from fossil fuels [1] and development of alternative energy sources from plants and microbial origin is necessary $[2,3]$ as the existing fossil reserves only for few decades. Biofuels substitute to fossil derived fuels due to similar physicochemical properties [4]. However, sustainability of biofuel depends on the land use, competing with food crops, water and fertilizer demand [5. Microalgae have advantages than terrestrial oil crops due to their high oil content and rapid biomass production [6, 7]. Commercialization of microalgae derived fuels is expensive due to the cost of heterotrophic growth nutrient. Replacing the chemical medium with low cost raw materials could reduce the problems associated with large scale cultivation of microalgae. Focusing on organic waste resources as feedstock for biodiesel production by microalgae is one effective method to produce economically viable biofuel. Agro-industrial wastes that are rich in sugars, proteins, lipids, vitamins and minerals are used as raw materials for the production of high-value products by microorganisms [8]. About 30-50\% fruit portion is discarded as waste which contain carbohydrates as major components. Fruit wastes such as peels, pomace and seeds could be a good feedstock [9] and contains higher reducing sugar values. Pre-treatment of fruit wastes alters the physio-chemical-biological characteristics resulting in release of sugars and nutrients [10]. Growth medium influences the growth rate, biomass and lipid production in microalgae and selection of appropriate pre-treatment is necessary to produce a growth medium from fruit wastes.

Biomass and lipid content of microalgae could be increased by choosing the optimum nutrient regime. Use of natural wastes as source of growth medium will not only fulfil the nutrient requirements of microalgae but also reduce the cost of growth medium. Microalgae are being cultivated in various culture media $[11,12,13]$. Hydrolysates prepared from fruit wastes could serve as suitable nutrient source due to the presence of carbohydrates and other nutrients. Pre-treatment methodologies can be categorized into physical, chemical and biological treatments or any combination of them [14]. Various hydrolysis methods are used and selection of suitable method for higher biomass and lipid accumulation could reduce the cost of biofuel production. Another reason for selection of pretreatment methods is that efficiencies depend on the organic waste characteristics [15]. Maximizing 
the bioavailability of nutrients is an important factor in pre-treatment as loss of carbohydrates occurs during conventional methods.

This study aimed to investigate the integrated microalgae cultivation process consisting of hydrolysis of fruit wastes and microalgae growth on the resulting hydrolysate using Chlorella vulgaris for biomass and lipid accumulation. Effects of three different pre-treatments (enzyme, aqueous and acid) of fruit waste hydrolysates on growth and lipid production were investigated and results are discussed.

\section{MATERIALS AND MeTHOdS}

\section{Enzyme hydrolysates (EH)}

The fruit wastes were collected from the local markets of Bangalore, Karnataka, India and washed to remove the extraneous matter. Fruit wastes were mixture of wastes from banana, sapota, sweet lime, orange, apple, mango, pomegranate, watermelon, musk melon and papaya. The peels were separated, oven dried at $40^{\circ} \mathrm{C}$, ground and sieved through mesh screen. The samples thus prepared were treated with cellulase and pectinase (w/v) followed by placing in a water bath at $50^{\circ} \mathrm{C}$ for 1 hour. The enzymatic hydrolysates of the fruit wastes were diluted using sterile distilled water, autoclaved and used as growth medium.

\section{Aqueous hydrolysates (AQH)}

The fruit peels were sun dried, ground into fine powder using a electric blender to obtain a fruit peel with particle size of 80/100 mesh. Hydrolysates were prepared by dissolving $10 \mathrm{~g}$ of ground fruit peels in $100 \mathrm{~mL}$ of distilled water, sterilized and filtered using Whatman's filter paper (No.1). The filtrates were diluted in sterile distilled water and used for algae cultivation.

\section{Acid hydrolysates (ACH)}

Fruit wastes were added with $6 \%$ sulfuric acid solution $(50: 50 \mathrm{w} / \mathrm{v})$ and incubated at $50^{\circ} \mathrm{C}$ for $1 \mathrm{~h}$. After being cooled, the hydrolysate was centrifuged at $5000 \mathrm{rpm}$ for $10 \mathrm{~min}$ and then the supernatant was diluted at varying concentrations and autoclaved for $121^{\circ} \mathrm{C}$ for 15 mins for microalgae cultivation.

\section{Batch cultivation}

Batch cultivation was carried out in a $500 \mathrm{~mL}$ flask containing $150 \mathrm{~mL}$ of various concentrations of enzymatic, aqueous and acid hydrolysates of fruit wastes. The $\mathrm{pH}$ of the medium was adjusted to 6.8, and the alga $(\sim 5 \% \mathrm{v} / \mathrm{v})$ was inoculated and cultivated in an orbital shaker with shaking $(120 \mathrm{rpm})$ at $25^{\circ} \mathrm{C}$. A $12 / 12$-h on/off light cycle $\left(200 \mu \mathrm{mol} \mathrm{m} \mathrm{s}^{-1}\right)$ was applied for a period of 14 days.

\section{Specific growth rate and Biomass productivity}

Specific growth rate $\mu\left(\mathrm{d}^{-1}\right)$ of the microalgae was calculated according to the following formula [16].

$$
\mu=\frac{\ln \left(\mathrm{N}_{\mathrm{t}} / \mathrm{N}_{0}\right)}{\mathrm{T}_{\mathrm{t}}-\mathrm{T}_{0}}
$$

Where, $\mathrm{N}_{t}$ and $\mathrm{N}_{0}$ are the dry cell weight concentration $\left(\mathrm{g} \mathrm{L}^{-1}\right)$ at the end $\left(\mathrm{T}_{\mathrm{t}}\right)$ and start $\left(\mathrm{T}_{0}\right)$ of $\log$ phase respectively.

Biomass $\left(\mathrm{g} \mathrm{L}^{-1}\right)$ of $C$. vulgaris grown in fruit hydrolysates medium was determined by measuring the optical density of samples at $600 \mathrm{~nm}\left(\mathrm{OD}_{600}\right)$ using UV-Vis spectrophotometer. Biomass concentration was then calculated by multiplying $\mathrm{OD}_{600}$ values with 0.6 , a predetermined conversion factor obtained by plotting $\mathrm{OD}_{600}$ versus dry cell weight (DCW). DCW was determined gravimetrically by centrifuging the algal cells $(3,000 \times \mathrm{g}, 10 \mathrm{~min})$ and drying and the biomass yield was calculated from the Eq.(2)

Biomass yield $(\mathrm{g} / \mathrm{l})=\left(\mathrm{B}_{\mathrm{t}}-\mathrm{B}_{0}\right) \times$ Volume of culture $\quad \ldots \ldots \ldots \ldots \ldots$. Eq. (1) where $B_{t}$ was the biomass concentration at the end of cultivation period $\left(T_{t}\right)$ and $B_{0}$ is the initial biomass concentration at the beginning of the cultivation period $\left(\mathrm{T}_{0}\right)$.

\section{Biochemical characterization of the isolates}

Total proteins were extracted using alkali method and estimated using Bovine Serum Albumin as internal standard [17]. Total carbohydrates were extracted using hot alkaline solution [18] and estimated by anthrone method [19]. 
Total photosynthetic pigments were estimated by centrifuging the algal cells at $8000 \mathrm{rpm}$ for $10 \mathrm{mins}$. The pellets were treated with $100 \%$ acetone $(5 \mathrm{~mL})$ and kept it overnight at $25^{\circ} \mathrm{C}$ in dark condition. After the incubation, the sample was centrifuged and the optical density of the supernatant was measured at 644, 661 and $470 \mathrm{~nm}$. The levels of pigments were quantified by using the following formula [20].

$$
\begin{aligned}
& \text { Chlorophyll a }(\mathrm{mg} / \mathrm{L})=11.24 \times \mathrm{A}_{661.6}-2.404 \times \mathrm{A}_{644.8} \\
& \text { Chlorophyll b }(\mathrm{mg} / \mathrm{L})=20.13 \times \mathrm{A}_{644.8}-4.19 \times \mathrm{A}_{661.6} \\
& \text { Total chlorophyll }(\mathrm{mg} / \mathrm{L})=7.05 \times \mathrm{A}_{661.6}+18.09 \times \mathrm{A}_{644.8} \\
& \text { Total carotenoids }(\mathrm{mg} / \mathrm{L})=1000 \times \mathrm{A}_{470}-1.9 \times \mathrm{Chl} \text { a }-63.14 \times \mathrm{Chl} \mathrm{b} / 214
\end{aligned}
$$

\section{Lipid extraction}

The algal cells were harvested by centrifugation, dried and the total lipids were extracted by solvent extraction method [21]. A 2:1 mixture of chloroform and methanol was added to the biomass and sonicated for $10 \mathrm{~min}$. Chloroform layer containing lipid fraction was separated using a separating funnel and $2 \mathrm{~g}$ anhydrous $\mathrm{Na}_{2} \mathrm{SO}_{4}$ was added for removing moisture. The lipid fraction was taken in a pre-weighed round bottom flask and the lipid weight was determined after evaporation of chloroform in a rotary evaporator. Lipid yield was expressed as percentage of the dry cell weight of algal biomass $(\% \mathrm{DCW})$.

\section{Fatty acids extraction and analysis}

Fatty acids were extracted from $50 \mathrm{mg}$ dried algal cells with $1 \mathrm{~mL}$ of $\mathrm{NaOH}-\mathrm{CH}_{3} \mathrm{OH}$. To each aliquot, $0.1 \mathrm{~mL}$ of an internal standard of $10 \mathrm{~g} / \mathrm{L}$ tridecanoic acid (C13:0) dissolved in chloroform was added for fatty acid quantification. The mixture was shaken for $10 \mathrm{~min}$ at $75^{\circ} \mathrm{C}$ in a waterbath and cooled to room temperature. Then, $2 \mathrm{~mL}$ of boron trifluoride-methanol solution $(1: 2, \mathrm{v} / \mathrm{v})$ was added, and the mixture was shaken for $10 \mathrm{~min}$ at $75^{\circ} \mathrm{C}$ and cooled to room temperature. Later, $0.3 \mathrm{~mL}$ of saturated salt solution was added to make a layered solution. Subsequently, $2 \mathrm{~mL}$ of hexane was added, and the mixture was centrifuged.

The upper fatty acids layer was subjected to Gas chromatography mass spectrometry analysis on Thermo Scientific TRACE GC Ultra comprising an Thermo DSQII auto-sampler equipped with Zebron ZB 5 MS column $(30 \mathrm{~m} \times 0.25 \mathrm{~mm} \times 0.25 \mu \mathrm{m})$. Helium was used as a carrier gas at a constant flow rate of $1.0 \mathrm{~mL} / \mathrm{min}$ and an injection volume of $1 \mu \mathrm{L}$ was employed in a splitless mode with the solvent delay time of $5 \mathrm{~min}$ and injection temperature was $250^{\circ} \mathrm{C}$. The initial temperature was $40^{\circ} \mathrm{C}$ with a hold time of $2 \mathrm{~min}$ and the ramp was $300^{\circ} \mathrm{C}$ at a rate of $10^{\circ} \mathrm{C} / \mathrm{min}$ for a hold period of $5 \mathrm{~min}$. Fatty acids were identified by a direct comparison of their mass spectral pattern and retention index with the NIST 05 mass spectral database. Data are reported as an average of triplicate measurements.

\section{RESUlTS AND DiscuSSION}

Chemical composition of hydrolysates obtained through various pre-treatment methods is presented in Table-1. Total ash content was highest in acid hydrolysate (4.49\%) and the total solids were highest in aqueous hydrolysate $(28.81 \%)$. It was observed that total protein and reducing sugar content was higher in enzyme hydrolysate $(6.31 \%$ and $26.47 \%)$.

Table 1. Chemical composition percentage of fruit waste hydrolysates under various pre-treatment methods

\begin{tabular}{|l|c|c|c|}
\hline & Enzymatic & Aqueous & Acid \\
\hline Total Ash & $3.83 \pm 0.20$ & $2.69 \pm 0.17$ & $4.49 \pm 0.14$ \\
\hline Total Solids & $27.59 \pm 0.10$ & $28.81 \pm 0.50$ & $20.67 \pm 0.20$ \\
\hline Total dietary fibre & $32.56 \pm 0.61$ & $33.75 \pm 0.20$ & $30.49 \pm 0.34$ \\
\hline Protein & $6.31 \pm 0.20$ & $6.14 \pm 0.01$ & $5.23 \pm 0.31$ \\
\hline Reducing sugar & $26.47 \pm 0.03$ & $22.37 \pm 0.06$ & $24.86 \pm 0.02$ \\
\hline
\end{tabular}

Various concentrations viz., 25\%, 50\%, $75 \%$ and $100 \%$ of the hydrolysates were prepared in distilled water and used as growth medium to cultivate $C$. vulgaris for a period of 14 days. The effect of fruit waste hydrolysate medium on the growth of microalgae was determined by calculating specific growth rate, biomass yield and pigment content (Table-2). Growth rate was varied with type of hydrolysates and concentration. Enzyme hydrolysates (EH) medium produced highest specific growth 
rate of $0.62 \mu \mathrm{d}^{-1}$ at $75 \%$ concentration followed by acid hydrolysates $(\mathrm{ACH})$ medium at the same concentration whereas, specific growth rate of $0.56 \mu \mathrm{d}^{-1}$ was observed in $100 \%$ aqueous hydrolysate $(\mathrm{AQH})$ medium. Biomass yield $\left(\mathrm{mg} \mathrm{L}^{-1}\right)$ was calculated using the biomass concentration at the end and initial cultivation period and highest yield was obtained in EH medium (47.6 $\left.\mathrm{mg} \mathrm{L}^{-1}\right)$ which was $8 \%$ higher than $\mathrm{AQH}$ medium. It was also noted that the biomass yield was reduced with increased hydrolysates concentration. There was a 5\% reduction of biomass yield in EH medium when the concentration was increased from $75 \%$ to $100 \%$ whereas $13 \%$ reduced yield was observed in ACH medium. Both total chlorophyll and carotenoid contents were highest in EH medium followed by $\mathrm{ACH}$ medium.

\begin{tabular}{|c|c|c|c|c|c|}
\hline Hydrolysates & $\begin{array}{l}\text { Specific Growth } \\
\text { rate }\left(\mu d^{-1}\right)\end{array}$ & $\begin{array}{c}\text { Biomass yield } \\
\left(\mathrm{mg} \mathrm{L}^{-1}\right)\end{array}$ & $\begin{array}{c}\text { Total Chlorophyll } \\
\left(\mathrm{mg} \mathrm{L}^{-1}\right)\end{array}$ & $\begin{array}{c}\text { Total Carotenoid } \\
\left(\mathrm{mg} \mathrm{L}^{-1}\right)\end{array}$ & $\begin{array}{c}\text { Lipid Yield } \\
\left(\mathbf{m g ~ L}^{-1}\right)\end{array}$ \\
\hline \multicolumn{6}{|l|}{ EH } \\
\hline 25 & $0.47 \pm 0.05$ & $27.9 \pm 1.31$ & $1.47 \pm 0.04$ & $0.03 \pm 0.10$ & $9.06 \pm 0.22$ \\
\hline 50 & $0.56 \pm 0.07$ & $35.6 \pm 0.96$ & $2.19 \pm 0.20$ & $0.05 \pm 0.02$ & $9.27 \pm 0.03$ \\
\hline 75 & $0.62 \pm 0.01$ & $47.6 \pm 0.10$ & $3.61 \pm 0.27$ & $0.09 \pm 0.14$ & $12.57 \pm 0.08$ \\
\hline 100 & $0.59 \pm 0.10$ & $45.1 \pm 1.04$ & $2.34 \pm 0.07$ & $0.07 \pm 0.05$ & $10.34 \pm 0.14$ \\
\hline \multicolumn{6}{|l|}{$\overline{\mathrm{AQH}}$} \\
\hline 25 & $0.34 \pm 0.10$ & $19.3 \pm 0.87$ & $0.94 \pm 0.02$ & $0.03 \pm 0.01$ & $7.31 \pm 0.18$ \\
\hline 50 & $0.41 \pm 0.21$ & $27.9 \pm 0.05$ & $1.21 \pm 0.34$ & $0.04 \pm 0.21$ & $7.89 \pm 0.27$ \\
\hline 75 & $0.49 \pm 0.02$ & $41.2 \pm 0.64$ & $1.76 \pm 0.05$ & $0.06 \pm 0.04$ & $8.64 \pm 0.33$ \\
\hline 100 & $0.56 \pm 0.08$ & $43.6 \pm 0.11$ & $2.89 \pm 0.61$ & $0.05 \pm 0.11$ & $9.61 \pm 0.30$ \\
\hline \multicolumn{6}{|l|}{$\overline{\mathrm{ACH}}$} \\
\hline 25 & $0.31 \pm 0.05$ & $29.2 \pm 1.24$ & $1.98 \pm 0.39$ & $0.04 \pm 0.15$ & $8.32 \pm 0.16$ \\
\hline 50 & $0.48 \pm 0.12$ & $41.3 \pm 0.04$ & $3.01 \pm 0.05$ & $0.08 \pm 0.16$ & $7.96 \pm 0.25$ \\
\hline 75 & $0.59 \pm 0.02$ & $45.9 \pm 2.02$ & $2.47 \pm 0.15$ & $0.07 \pm 0.03$ & $11.74 \pm 0.09$ \\
\hline 100 & $0.58 \pm 0.06$ & $39.5 \pm 0.87$ & $1.62 \pm 0.07$ & $0.04 \pm 0.32$ & $8.51 \pm 0.31$ \\
\hline
\end{tabular}

Lipid yield was determined gravimetrically and was highest $\left(12.57 \mathrm{mg} \mathrm{L}^{-1}\right)$ in cells grown in enzyme hydrolysate medium at $75 \%$ concentration. No significant change in the lipid yield of cells from acid hydrolysate medium when compared to EH medium. However the yield was low in aqueous hydrolysate medium which is $31 \%$ and $26.4 \%$ lower than $\mathrm{EH}$ and $\mathrm{ACH}$ respectively. It was also noted that the lipid yield was decreasing when the hydrolysate concentration was increased from $75 \%$ to $100 \%$ in the case of $\mathrm{EH}$ and $\mathrm{ACH}$ media. But there was a $10.1 \%$ increase when the aqueous hydrolysate concentration was increased to $100 \%$. Lipid extracts from highest lipid content cells were subjected to gas chromatography analysis and the results revealed the presence fatty acid belonging to the groups of C14:0, 16:0 and C18:0. Myristic acid, palmitic acid, palmitoleic acid, stearic acid and linoleic acid were found in cells derived from the all three hydrolysates media. The presence of oleic acid in EH media was noted as additional fatty acid methyl ester.

Low cost and alternative carbon sources are desirable to make commercialization of biofuel viable. Heller et al., [22] observed the oil production rate of $1.9 \mathrm{~g} \mathrm{~L}^{-1}$ day ${ }^{-1}$ using papaya waste as growth medium for the cultivation of $C$. protothecoides. Enzymatic hydrolysates of sweet sorghum have produced a lipid yield of $535.5 \mathrm{mg} \mathrm{L}^{-1}$ day $^{-1}$ by $C$. protothecoides [23]. Pre-treatment of fruit wastes disrupts the cell wall and makes the carbohydrates accessible to cellulose degrading enzymes [24]. Li et al., [25] reported the biomass and lipid productivity by $C$. pyrenoidosa as 1.10 and $0.62 \mathrm{~g} \mathrm{~L}^{-1}$ day $^{-1}$ when using rice straw hydrolysate medium. Liu et al., (2012) observed biomass productivity of $1.55 \mathrm{~g}$ $\mathrm{L}^{-1}$ day $^{-1}$ and $0.71 \mathrm{~g} \mathrm{~L}^{-1}$ day $^{-1}$ by Chlorella zofingiensis while using cane molasses as carbon source. Lu et al., [26] used cassava starch hydrolysates to cultivate Chlorella species and observed biomass concentration and oil yield as $53.6 \mathrm{~g} \mathrm{~L}^{-1}$ and $28.4 \mathrm{~g} \mathrm{~L}^{-1}$ respectively. Yan et al., [27] reported biomass yield and oil yield of $70.9 \mathrm{~g} \mathrm{~L}^{-1}$ and $40.8 \mathrm{~g} \mathrm{~L}^{-1}$ by using molasses hydrolysate medium while cultivating $C$. protothecoides. Cane molasses pretreated with cation exchange resin produced 1.55 and $0.71 \mathrm{~g} \mathrm{~L}^{-1}$ day $^{-1}$ of biomass and lipid productivity in Chlorella zofingiensis (Liu et al., 2012) [28]. Park et al., [29] indicated 3.4 times increase in biomass and 4.5 times FAMEs in C. vulgaris grown in the presence of orange peel extract. These studies were performed with different agro industrial wastes 
using enzyme and acid hydrolysates. Fruit wastes hydrolysates are additional feedstock in the mixotrophic cultivation of Chlorella [30].

In this study the effect of various pre-treatment methods on the growth and lipid production of $C$. vulgaris was examined in addition to determination of suitable an optimal concentration of fruit waste hydrolysates. Difference among the growth parameters and lipid yield observed among the hydrolysates indicates the efficacy of using enzymes during pre-treatment process.

\section{REFERENCES}

[1] Doll C.N., Pachauri S., Estimating rural populations without access to electricity in developing countries through night-time light satellite imagery. Energy Policy. 2010. 38(10): 5661-5670.

[2] Berg P., Boland A., Analysis of ultimate fossil fuel reserves and associated $\mathrm{CO}_{2}$ emissions in IPCC scenarios. Nat. Resour. Res. 2014. 23 (1): 141-158.

[3] Gaurav N., Sivasankari S., Kiran G.S., Ninawe A., Selvin J., Utilization of biomass for sustainable biofuels: A Review. Renewable and Sustainable Energy Reviews. 2017. 73: 205-214.

[4] Zhang Z., O'hara I.M., Mundree S., Gao B., Ball A.S., Zhu N., et al. Biofuels from food processing wastes. Curr. Opin. Biotechnol. 2016. 38: 97-105.

[5] Timilsina G.R., Shrestha A., An overview of global markets and policies. In: Timilsina, G.R., Shrestha, A. (Eds.). The Impacts of Biofuels on the Economy, Environment, and Poverty. Springer, New York, 2014. pp. 1-14.

[6] Ashraful A.M., Masjuki H.H., Kalam M.A., Rizwanul Fattah I.M., Imtenan S., Shahir, S.A., et al. Production and comparison of fuel properties, engine performance, and emission characteristics of biodiesel from various non-edible vegetable oils: a review. Energy Convers. Manag. 2014. 80: 202-228.

[7] Jin M., Slininger P.J., Dien B.S., Waghmode S., Moser B.R., Orjuela, A., Microbial lipid-based lignocellulosic biorefinery: feasibility and challenges. Trends Biotechnol. 2015. 33: 43-54.

[8] Cheirsilp B., Suwammarat W., Niyomdecha R., Mixed culture of oleaginous yeast Rhodotorula glutinis and microalga Chlorella vulgaris for lipid production from industrial wastes and its use as biodiesel feedstock. New Biotechnol. 2011, 28: 362-368.

[9] Banerjee J., Singh R., Vijayaraghavan R., MacFarlane D., Patti A.F., Arora A., Bioactives from fruit processing wastes: Green approaches to valuable chemicals. Food Chemistry. 2017. 225: $10-22$.

[10] Hao H.N., Karthikeyan O.P., Heimann K., Bio-refining of carbohydrate rich food waste for biofuels. Energies. 2015. 8(7): 6350-6364.

[11] Pleissner D., Lam W.C., Sun Z., Lin C.S.K., Food waste as nutrient source in heterotrophic microalgae cultivation. Bioresour. Technol., 2013. 137: 139-146.

[12] Wu S., Xu X.R., Sun K.F., Li H.B., Effects of fruit waste hydrolysates on biomass and chlorophyll a fluorescence parameters of Chlorella pyrenoidosa. Int. J. Environ. Bioener. 2014. 9(2): 105-121.

[13] Sibi G., Low cost carbon and nitrogen sources for higher microalgal biomass and lipid production using agricultural wastes. Journal of Environmental Science and Technology. 2015. 8(3): 113-121.

[14] Chiaramonti D., Prussi M., Ferreo S., Oriani L., Ottonello P., Torre P., Cherchi F., Review of pretreatment processes for lignocellulosic ethanol production, and development of an innovative method. Biomass Bioenerg. 2012. 46: 25-35.

[15] Karthikeyan, O.P., Visvanathan, C., Bio-energy recovery from high-solid organic substrates by dry anaerobic bio-conversion processes: a review. Rev. Environ. Sci. Biotechnol. 2013. 12(3): 257-284.

[16] Levasseur M., Thompson P.A., Harrison P.J., Physiological acclimation of marine phytoplankton to different nitrogen sources. J. Phycol. 1993. 29: 587-595.

[17] Lowry O.H., Rosebrough N.J., Farr A.L., Randall RJ., Protein measurement with the Folin phenol reagent. J. Biol. Chem, 1951. 193: 265-275. 
[18] Leyva, A., Quintana, A., Sanchez, M., Rodriguez, E.N., Cremata, J., Sanchez, J.C., Rapid and sensitive anthrone-sulfuric acid assay in microplate format to quantify carbohydrate in biopharmaceutical products: Method development and validation. Biologicals. 2008. 36: 134141.

[19] Gerhardt, P., Murray, R.G.E., Wood, W.A. and Krieg, N.R. Methods for general and molecular bacteriology. 1994. ASM, Washington DC.

[20] Lichtenthaler H.K., Chlorophylls and carotenoids, the pigments of photosynthetic membranes. In: Douce, R., Packer, L. (Eds.), Methods Enzymol., 148. Academic Press Inc., 1987. New York, pp. 350-382.

[21] Bligh E.G., Dyer W.J., A rapid method of total lipid extraction and purification. Can. J. Biochem. Physiol. 1959. 37: 911-917.

[22] Heller W.P., Kissinger K.R., Matsumoto T.K., Keith L.M., Utilization of papaya waste and oil production by Chlorella protothecoides. Algal Research. 2015. 12: 156-160.

[23] Gao C., Zhai Y., Ding Y., Wu Q., Application of sweet sorghum for biodiesel production by heterotrophic microalga Chlorella protothecoides, Appl. Energy. 2010. 87: 756-761.

[24] Choi I.S., Kim J.H., Wi S.G., Kim K.H., Bae H.J., Bioethanol production from mandarin (Citrus unshiu) peel waste using popping pretreatment. Applied Energy. 2013. 102: 204-210.

[25] Li P., Miao X., Li R., Zhong J., In situ biodiesel production from fast-growing and high oil content Chlorella pyrenoidosa in rice straw hydrolysate, J Biomed Biotechnol. 2011. 141207.

[26] Lu Y., Zhai Y., Liu M., Wu Q., Biodiesel production from algal oil using cassava (Manihot esculenta Crantz) as feedstock, J. Appl. Phycol. 2010. 22: 573-578.

[27] Yan D., Lu Y., Chen Y.F., Wu Q., Waste molasses alone displaces glucose-based medium for microalgal fermentation towards cost-saving biodiesel production, Bioresour. Technol. 2011. 102: 6487-6493.

[28] Liu J., Huang J., Jiang Y., Chen, F., Molasses-based growth and production of oil and astaxanthin by Chlorella zofingiensis, Bioresour. Technol. 2012. 107: 393-398.

[29] Park W.K., Moon M., Kwak MS., Jeon S., Choi GG., Yang JW., Lee B., Use of orange peel extract for mixotrophic cultivation of Chlorella vulgaris: increased production of biomass and FAMEs. Bioresour Technol. 2014. 171: 343-349.

[30] Wu S., Xu XR., Sun K.F., Li H.B., Effects of fruit waste hydrolysates on biomass and chlorophyll a fluorescence parameters of Chlorella pyrenoidosa. Int. J. Environ. Bioener. 2014. 9(2): 105-121. 